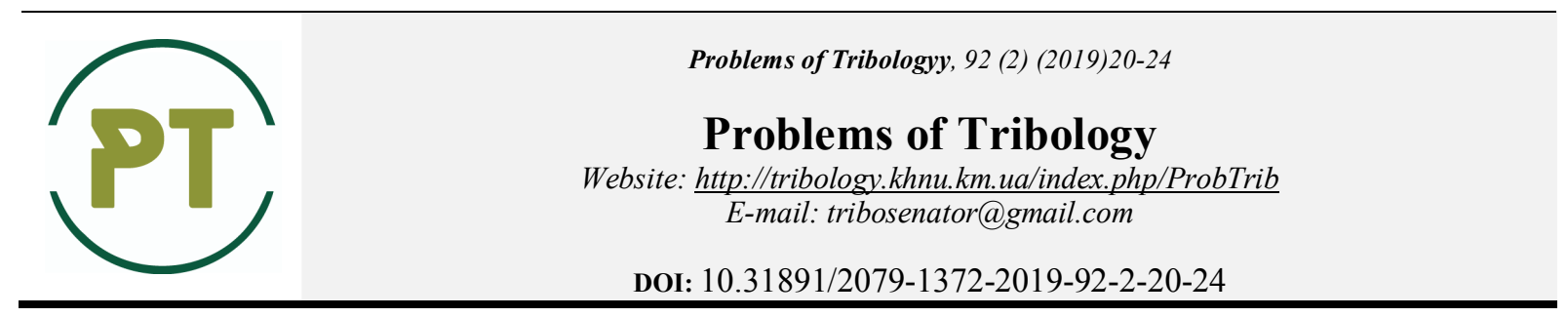

\title{
Assessment of the properties of hardened by nanocoating oil scraper piston rings by an optic-mathematical method
}

\author{
T.S.Skoblo ${ }^{1}$, A.I. Sidashenko ${ }^{1}$, T.V. Maltsev ${ }^{2 *}$, V.N.Romanchenko ${ }^{1}$ \\ ${ }^{I}$ Kharkiv Petro Vasylenko National Technical University of Agriculture, Kharkiv, Ukraine, \\ ${ }^{2}$ State Enterprise "Malyshev Plant", Kharkiv, Ukraine \\ ${ }^{*}$ E-mail: taras.maltsev@gmail.com
}

\begin{abstract}
The paper presents an optical-mathematical evaluation of the physic-mechanical properties of the D100 diesel-generator oil scraper piston ring surface hardened by multi-layer ion-plasma nanocoating TiN/CrN. The application parameters of multilayer nanocoating and the sequence of its layers are shown. The values of wear and microhardness of the hardened and serial rings are given. The increase in wear resistance of the hardened product is shown to be 12 times in weight and 4 times in the degree of increase in the size of its friction surface. A method for evaluating properties using the mathematical operators of the laplacian and divergences in their different variations is proposed. A correlation between the properties of the results of tests for friction and wear with using a mathematical description of structure formation was revealed. The minimal difference of the friction zone and the initial surface of the hardened ring, which does not exceed $16 \%$, is revealed. The difference between the initial surface and the friction zone in the serial ring is shown, which reaches up to $42 \%$ on average in terms of indicators. A substantial deviation of the values of the friction zone mathematical operators of the serial ring from the TiN/CrN hardened by ion-plasma nanocoating was confirmed, which in some cases reaches up to $42 \%$ on average.
\end{abstract}

Key words: multilayer nanocoating, piston ring, friction and wear, microhardness, optical-mathematical analysis, structure formation.

\section{Introduction}

Previously conducted bench tests for friction and wear of serial oil scraper piston rings of D100 diesel generator have relatively low wear resistance [1]. The use of a multilayer ion-plasma nanocoating TiN/CrN allowed to reduce the total weight wear of the hardened ring by 12 times relatively to the serial ones $(1.0 \mathrm{mg} v$ vs. $12.1 \mathrm{mg}$ ) and by 4 times the increase of the ring friction zone [2]. However, there is an interest to study the mechanism of wear of hardened rings, taking into account their operating conditions. For this purpose, an attempt to study the original surface and the friction area was made using an optic- mathematical modeling method. Such a method makes it possible to detect relationships between friction parameters, for example, speed and the structure of the contacting surface of the ring, which is estimated by approximation of digital images of products. In addition, this method allows to assess the degree and nature of the generated stresses of the rubbing surfaces and locally determine zones of their concentration [3 - 8].

The aim of the work is a mathematical assessment of the working surface properties of the serial piston rings and hardened by multi-layer ion-plasma nano-coating TiN/CrN according to the results of their bench tests for friction and wear at a constant sliding speed.

\section{Methods and results of research}

To ensure a high wear resistance of the ring, a multilayer ion-plasma coating of the TiN/CrN system was deposited by the "Bulat" type equipment. The deposition of the coating was carried out at an arc current of $I=100 \mathrm{~A}$ and a bias voltage of the substrate of $U=-200 \mathrm{~V}$. Six layers of $\mathrm{CrN}$ and five layers of TiN were alternately applied, previously spraying a sublayer of pure $\mathrm{Cr}$ with a thickness of $\sim 50 \mathrm{~nm}$. The thickness of a TiN layer is $49 \mathrm{~nm}$, and a CrN layer is $240 \mathrm{~nm}$. The total thickness of the multilayer coating is $1.7 \mu \mathrm{m}$. 
By standard production technology, these products are galvanically tinned to reduce the period of their burn-in due to the formation of a layer of tin on the working surface. The tin coating has a non-uniform grain structure consisting of individual fragments and ironed areas. Serial rings were tested together with a hardened $\mathrm{TiN} / \mathrm{CrN}$ ion-plasma coating for comparative evaluation of their tendency to wear.

To assess the nature and rate of wear of such rings, bench tests were carried out on a specialized machine under conditions of sliding friction during reciprocation motion. In the machine, according to the considered variants, they installed one cylinder liner sample and two samples of the piston rings. The moving part was a sample of cylinder liner. Samples of the cylinder liners are made of gray cast iron and subjected to phosphatization (serial technology). A sketch of the cross section of the oil scraper piston ring, as well as the test scheme is presented in Fig. 1 and 2 respectively.

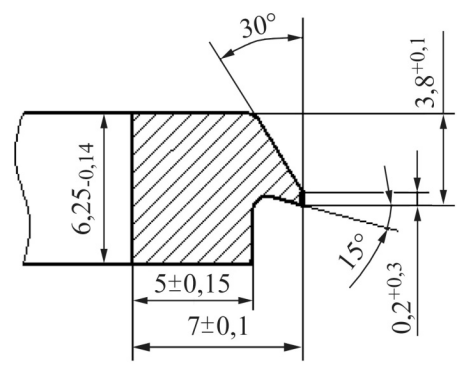

Fig. 1. Sketch of the cross section of the oil scraper piston ring of D100 diesel engine

The constant moving speed of the moving specimens for each variant was $1.3 \mathrm{~m} / \mathrm{s}$. The load $(P)$ for all samples was selected $-3.35 \mathrm{~kg}$, which corresponds to the specific pressure on the working surface of the ring $0.8 \mathrm{MPa}$. This allowed to obtain a modeling process of wear for a shorter test period.

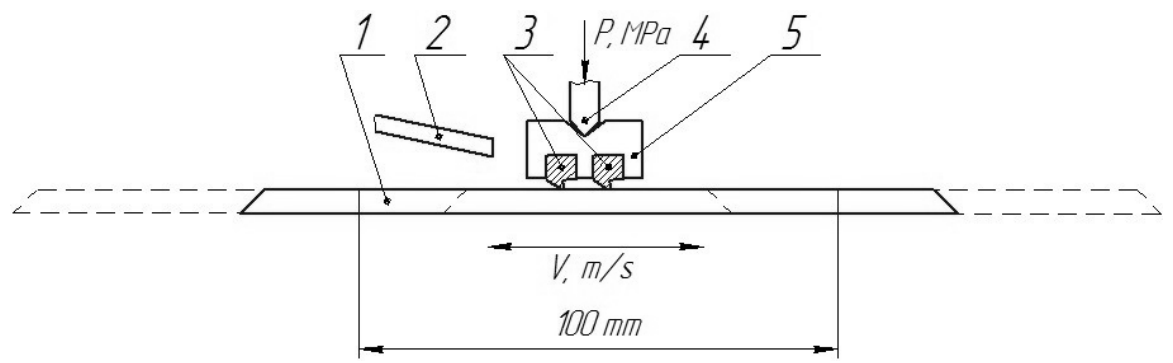

Fig. 2 . Scheme of testing samples of oil scraper piston rings:

1 - a cylinder liner sample;

2 - an oil drip pipe;

3 - samples of oil scraper piston rings;

4 - a cargo;

5 - a sample holder

The length of the stroke of the cylinder liner sample is $100 \mathrm{~mm}$ (see Fig. 2). The flow of oil brand M14$\mathrm{B}_{2}$ in the friction zone was 1-2 drops per minute.

The total test time is 100 hours. Of them:

- first stage (extra running) - 3 hours,

- the second stage of the main tests - 25 hours,

- the third stage of the main tests - 72 hours

The total length of the friction traversed path of the samples was $468 \mathrm{~km}$. Between the stages of testing, the change in microhardness was fixed, as well as the height of the working surfaces of the rings. The results of microhardness measurement are presented in Fig. 3

Table 1

Change the size of the working surfaces of the serial and hardened piston rings after testing

\begin{tabular}{|c|c|}
\hline $\begin{array}{c}\text { № } \\
\text { of a ring }\end{array}$ & $\begin{array}{c}\text { Increasing the size of } \\
\text { the working surface on, } \mathrm{mm}\end{array}$ \\
\hline \multicolumn{2}{|c|}{ serial ring } \\
\hline 1 & 0,04 \\
\hline 2 & 0,04 \\
\hline \multicolumn{2}{|c|}{0,01} \\
\hline 1 & 0,01 \\
\hline
\end{tabular}




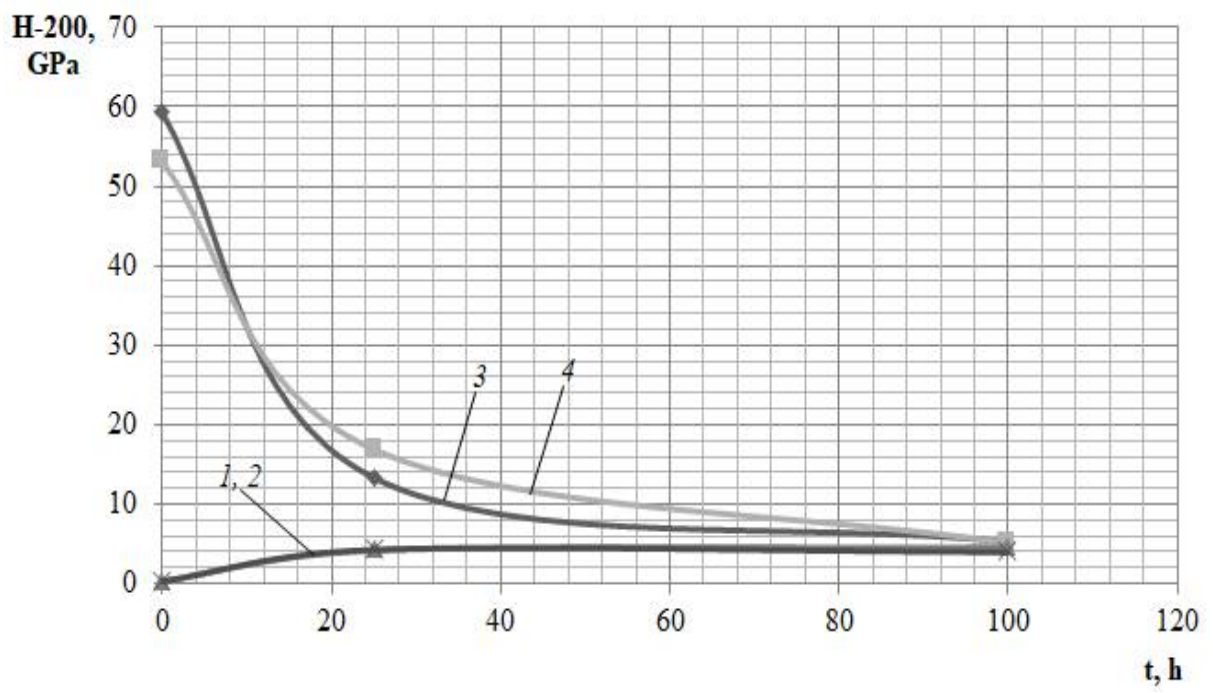

Fig. 3. Change of microhardness of serial $(1,2)$ and hardened $(3,4)$ piston rings during testing

For the mathematical evaluation of the structure, the methods described in [3 - 8] were used. With the help of a specially developed computer program, 2 digital images in the bmp format of hardened and serial piston rings of D100 diesel generator were tested (Fig. 4 a, b). At the same time, various variations of mathematical operators - Laplacians and divergences - were used. For the convenience of identifying dependencies, each image was conventionally divided into 2 areas: the friction zone (Fig. 4, spectrum 2), which forms the working surface of the ring and the original (Fig. 4, spectrum 1), which is directly adjacent to it.

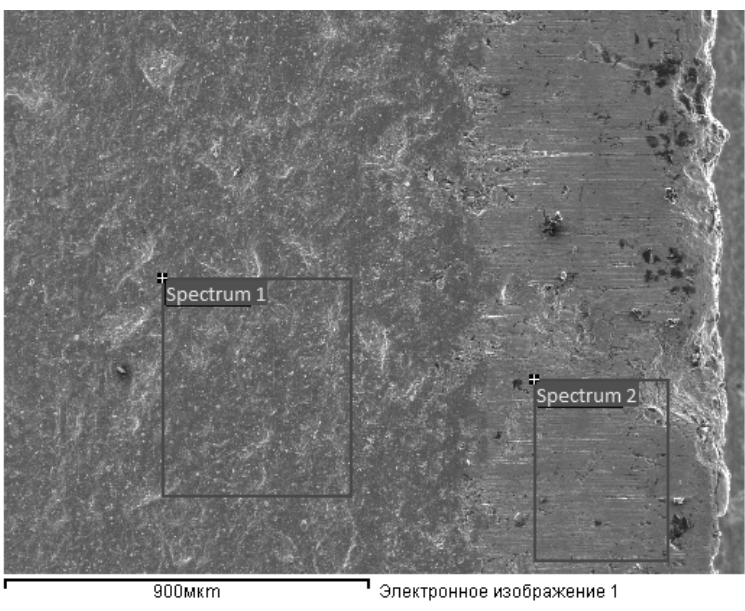

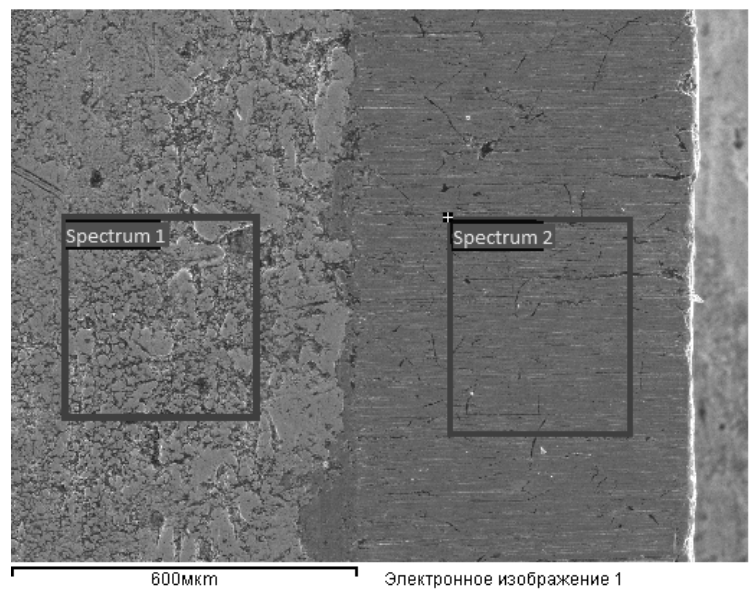

b

Fig. 4. Macrostructure of the initial surface (spectrum 1) and friction zone (spectrum 2) of the hardened (a) and serial (b) piston ring

The analysis of images revealed that in the tested serial ring, the average neutrality of the Laplacian, calculated by the basic formula, of the Laplacian at an angle of $90^{\circ}$ to the main one, the 3rd and 4th Laplacians, is higher in the friction zones relative to their original variants (Table 2). A similar picture is observed for the hardened piston ring with the exception of the laplacian at an angle of $90^{\circ}$ to the main one (see Table 2). However, it should be noted that the difference between the original and the friction surface of the serial ring is noticeably larger, on average by $11 \%$ for all indicators, and for hardened - by $1.5 \%$. This indicates about a lower level of influence of operating conditions on the change in structure after ion-plasma hardening of the ring, which is consistent with the results of tests for wear and microhardness.

The mean color functions, standard deviations, the generalized gradient, the total, 3rd and 4th Laplacians, and the divergence are characterized by decrease for the serial ring and an increase for hardened (Table 3 ). It should be noted that such results cause a high wear rate of the serial ring, and a high degree of wear resistance and hardened deformation (see Table 1). At the same time, the difference of the initial surfaces between the variants of the rings is, on average in terms of indicators, $32.5 \%$, and friction zones $-38.5 \%$ with the exception of color. The difference in the function of color is not significant and is only $3.8 \%$. It should be noted that the difference in performance between the surfaces before and after the tests is: for a serial ring - $41.5 \%$, and for hardened $-11.3 \%$. That is consistent with the results of the bench tests. 
Table 2

Average neutrality in terms of serial and hardened piston rings, tested at a sliding speed of $1.3 \mathrm{~m} / \mathrm{s}$

\begin{tabular}{|l|c|c|c|c|c|}
\hline $\begin{array}{c}\text { The studied } \\
\text { surface }\end{array}$ & $\begin{array}{c}\text { Main } \\
\text { Laplacian }\end{array}$ & $\begin{array}{c}\text { Laplacian } \\
\text { at 90 }\end{array}$ & $\begin{array}{c}\text { 3rd } \\
\text { Laplacian }\end{array}$ & $\begin{array}{c}\text { 4rd } \\
\text { Laplacian }\end{array}$ & Divergence \\
\hline \multicolumn{7}{|c|}{ a serial ring } \\
\hline Initial & 0,705 & 0,775 & 0,616 & 0,563 & 0,787 \\
\hline Zone of friction & 0,772 & 0,823 & 0,715 & 0,672 & 0,710 \\
\hline \multicolumn{7}{|c|}{ a hardened ring } \\
\hline Initial & 0,742 & 0,817 & 0,665 & 0,611 & 0,753 \\
\hline Zone of friction & 0,744 & 0,813 & 0,676 & 0,629 & 0,755 \\
\hline
\end{tabular}

Table 3

Average color and mathematical functions of serial and hardened piston rings

\begin{tabular}{|c|c|c|c|c|c|c|c|}
\hline $\begin{array}{c}\text { The studied } \\
\text { surface }\end{array}$ & Color & $\begin{array}{c}\text { Standard } \\
\text { deviation }\end{array}$ & $\begin{array}{c}\text { Generalized } \\
\text { gradient } \\
\text { Leneral } \\
\text { Laplacian }\end{array}$ & $\begin{array}{c}\text { 3rd } \\
\text { Laplacian }\end{array}$ & $\begin{array}{c}\text { 4rd } \\
\text { Laplacian }\end{array}$ & Divergence \\
\hline \multicolumn{7}{|c|}{ a serial ring } \\
\hline Initial
\end{tabular}

As table 4 shows, all indicators of a serial ring after tests go down, on average, by $31 \%$. The hardened ring shows an increase in the values of the main, 3rd and 4th Laplacians, on average, by $16 \%$. At the same time, the generalized gradient and divergence remained unchanged after operation. It should be noted that the surface of friction of the hardened ring for the same indicators exceeds the values of the serial, on average, by $42 \%$. This is associated with an increase in the level of wear resistance of the ring due to its ion-plasma hardening, as evidenced by the above calculations (see Tables 2 and 3).

Table 4

\section{Average values of the analyzed indicators of the serial and hardened piston ring}

\begin{tabular}{|l|c|c|c|c|c|}
\hline $\begin{array}{c}\text { The studied } \\
\text { surface }\end{array}$ & $\begin{array}{c}\text { Generalized } \\
\text { gradient }\end{array}$ & $\begin{array}{c}\text { General } \\
\text { Laplacian }\end{array}$ & $\begin{array}{c}\text { 3rd } \\
\text { Laplacian }\end{array}$ & $\begin{array}{c}\text { 4rd } \\
\text { Laplacian }\end{array}$ & Divergence \\
\hline \multicolumn{6}{|c|}{ a serial ring } \\
\hline Initial & 0,2 & 0,5 & 0,8 & 1,6 & 0,3 \\
\hline $\begin{array}{l}\text { Zone of } \\
\text { friction }\end{array}$ & 0,1 & 0,4 & 0,7 & 1,3 & 0,2 \\
\hline \multicolumn{7}{|c|}{ a hardened ring } \\
\hline Initial & 0,2 & 0,5 & 0,9 & 1,8 & 0,3 \\
\hline $\begin{array}{l}\text { Zone of } \\
\text { friction }\end{array}$ & 0,2 & 0,6 & 1,1 & 2,1 & 0,3 \\
\hline
\end{tabular}

\section{Conclusions}

As a result of the mathematical analysis of photographs of friction surfaces of a serial ring and with a multilayer ion-plasma nanocoating $\mathrm{TiN} / \mathrm{CrN}$, the following was established:

- dependencies were found between the results of testing two variants of rings and mathematical operators in the optical-mathematical description of structure formation; 
- a feature was revealed that consists in the minimum difference between the friction zone and the initial surface of the hardened ring, which in some cases ranges from $1.5 \%$ to $16 \%$;

- there was a significant difference between the original surface and the friction area in the serial ring, which is in the range from $11 \%$ to 42 in terms of performance;

- revealed a significant deviation of the values of the operators of the friction zone of the serial ring from the hardened one, which in some cases reaches, on average in terms of indicators, up to $42 \%$.

\section{References}

1. Skoblo T. S. Features of Wear of Oil-Scraper Piston Rings with Tin Coatings in Bench Tests for Friction and Wear / T. S. Skoblo, A. I. Sidashenko, E. A. Satanovskii, A. K. Oleinik, T. V. Maltsev // Materials Science, Vol. 53, Is. 4, 2018, - r. 501-507.

2. Skoblo T. S. Influence of Increased Sliding Speed on the Structure and Properties of Piston Rings with Ion-Plasma Coating / T. S. Skoblo, A. I. Sidashenko, I. E. Garkusha, A. V. Taran, R. M. Muratov, T. V. Maltsev // Problems of Atomic Science and Technology, Series: Plasma Physics (118) № 6, 2018, - p. 304 - 307.

3. Skoblo T. S. Primenenie kompyuternogo analiza metallograficheskih izobrazhenij pri is-sledovanii struktury vysokohromistogo chuguna / T. S. Skoblo, O. Yu. Klochko, E. L. Belkin // Zavodskaya laboratoriya. Diagnostika materialov, Moskva, t. 78, № 6, 2012 g. - s. 35-42.

4. Skoblo T. S. Ocenka stepeni neodnorodnosti karbidov geterogennyh splavov metodom opti-komatematicheskogo analiza pri pomoshi izmenchivosti uslovnyh cvetov / T. S. Skoblo, O. Yu. Klochko, E. L. Belkin, O. I. Trishevskij // Visnik HNTUSG im. P. Vasilenka. Resursozberigayuchi tehnologiyi, materiali ta obladnannya u remontnomu virobnictvi, Harkov, Vip. 168, 2016 g. - s. 174-186.

5. Skoblo T. S. Issledovanie struktury vysokohromistogo kompleksno legirovannogo chuguna $\mathrm{s}$ primeneniem metodov matematicheskogo analiza / T. S. Skoblo, O. Yu. Klochko, E. L. Belkin // Stal, № 3, 2012 g. - s.46-52.

6. Trishevskij O.I. Issledovaniya mikrostruktur geterogennyh splavov metodom matematiche-skogo analiza pri pomoshi sochetanij uslovnyh cvetov i absolyutnyh znachenij laplasianov / O. I. Trishevskij, T. S. Skoblo, O. Yu. Klochko, E. L. Belkin // Promyshlennost v fokuse, Harkov, №7 (31), 2015 g. - s.52-56.

7. Skoblo T. S. Opredelenie mikrotverdosti strukturnyh sostavlyayushih vysokohromistyh chu-gunov v rezultate matematicheskoj obrabotki ih izobrazhenij / T. S. Skoblo, O. Yu. Klochko, E. L. Belkin // Visnik HNTUSG im. P.Vasilenka. Problemi nadijnosti mashin ta zasobiv mehanizaciyi s/g virobnictva, Harkov, Vip. 151, 2014 g. - s.183-189.

8. Malcev T. V. Kompleksnaya ocenka ostatochnyh napryazhenij v porshnevyh kolcah / T. V. Malcev // Tehnichnij servis agropromislovogo, lisovogo ta transportnogo kompleksiv, m. Harkiv, № 10, 2017 r. - s. $80-87$.

Скобло Т.С., Сидашенко О.I., Мальцев Т.В. Оцінка властивостей зміцнених нанопокриттям маслоз'ємних поршневих кілець оптико-математичним методом

У роботі представлена оптико-математична оцінка експлуатаційних властивостей поверхні серійного і зміцненого багатошаровим іонно-плазмовим нанопокриттям TiN/CrN маслос'емного поршневого кільця дизель-генератора Д100. Показані параметри і послідовність нанесення багатошарового нанопокриття. Наведені значення зносу і мікротвердості зміцнених і серійних кілець. Показано збільшення зносостійкості зміцненого кільця в 12 разів, оціненої по втраті ваги, і в 4 рази за ступенем збільшення розміру поверхні тертя. Запропоновано методику оцінки властивостей з використанням математичних операторів Лапласіан і дивергенції в різних варіаціях. Виявлена залежність між властивостями за результатами випробувань на зношування і математичною оцінкою структуроутворення. Виявлена мінімальна різниця між зоною тертя і вихідною поверхнею зміцненого кільця, яка не перевищує 16 \%. Показана різниця між вихідною поверхнею і зоною тертя в серійному кільці, яка, в середньому за показниками, досягає $42 \%$. Підтверджено суттєве відхилення значень математичних операторів в зоні тертя серійного кільця від зміцненого іонно-плазмовим нанопокриттям TiN/CrN, яке в деяких випадках складає 42 \%.

Ключові слова: багатошарове нанопокриття, поршневі кільця, тертя і знос, мікротвердість, оптико-математичний аналіз, структуроутворення 